\title{
Short communication: An in vitro assessment of the antibacterial activity of plant-derived oils
}

\author{
K. A. E. Mullen, ${ }^{*}$ A. R. Lee,† R. L. Lyman,† S. E. Mason,‡ S. P. Washburn, ${ }^{*}$ and K. L. Anderson† ${ }^{1}$ \\ *Department of Animal Science, North Carolina State University, Raleigh 27695 \\ †Department of Population Health and Pathobiology, North Carolina State University, Raleigh 27607 \\ ‡Department of Biological Sciences, Campbell University, Buies Creek, NC 27506
}

\section{ABSTRACT}

Nonantibiotic treatments for mastitis are needed in organic dairy herds. Plant-derived oils may be useful but efficacy and potential mechanisms of action of such oils in mastitis therapy have not been well documented. The objective of the current study was to evaluate the antibacterial activity of the plant-derived oil components of Phyto-Mast (Bovinity Health LLC, Narvon, PA), an herbal intramammary product, against 3 mastitis-causing pathogens: Staphylococcus aureus, Staphylococcus chromogenes, and Streptococcus uberis. Plant-derived oils evaluated were Thymus vulgaris (thyme), Gaultheria procumbens (wintergreen), Glycyrrhiza uralensis (Chinese licorice), Angelica sinensis, and Angelica dahurica. Broth dilution testing according to standard protocol was performed using ultrapasteurized whole milk instead of broth. Controls included milk only (negative control), milk + bacteria (positive control), and milk + bacteria + penicillin-streptomycin (antibiotic control, at 1 and $5 \%$ concentrations). Essential oil of thyme was tested by itself and not in combination with other oils because of its known antibacterial activity. The other plant-derived oils were tested alone and in combination for a total of 15 treatments, each replicated 3 times and tested at $0.5,1,2$, and $4 \%$ to simulate concentrations potentially achievable in the milk within the pre-dry-off udder quarter. Thyme oil at concentrations $\geq 2 \%$ completely inhibited bacterial growth in all replications. Other plant-derived oils tested alone or in various combinations were not consistently antibacterial and did not show typical dose-response effects. Only thyme essential oil had consistent antibacterial activity against the 3 mastitis-causing organisms tested in vitro. Further evaluation of physiological effects of thyme oil in various preparations on mammary tissue is recommended to determine potential suitability for mastitis therapy.

Received December 5, 2013.

Accepted June 5, 2014.

${ }^{1}$ Corresponding author: kevin_anderson@ncsu.edu
Key words: mastitis, plant-derived oils, alternative to antibiotics, organic

\section{Short Communication}

Organic dairy products represented almost $6 \%$ of the entire US dairy market in 2010 (Organic Trade Association, 2011). Because organic dairies are prohibited from using synthetic antibiotics in cattle (Electronic Code of Federal Regulations, 2013), a need exists for effective alternatives to synthetic antibiotics to treat mastitis. Dairies with a 6-mo average bulk tank SCC over 250,000 cells $/ \mathrm{mL}$ had significantly higher prevalence of Staphylococcus aureus, Streptococcus spp., CNS, and Streptococcus agalactiae in organic herds compared with conventional herds (Pol and Ruegg, 2007a). In contrast, organic and conventional herds in North Carolina had similar prevalence of Staph. aureus, Streptococcus spp., CNS, and Corynebacterium spp. (Mullen et al., 2013).

Organic dairies have been reported to use a wide variety of nonantibiotic treatments for mastitis, from Aloe vera to vitamin supplements ( $\mathrm{Pol}$ and Ruegg, 2007b). Peer-reviewed clinical efficacy studies evaluating those alternatives are scarce (Ruegg, 2009), but anecdotal reports exist of the efficacy of plant essential oils for improvement of milk quality in dairy cattle (Karreman, 2007). Plant-derived oils are the main ingredients in one intramammary product, Phyto-Mast (Bovinity Health LLC, Narvon, PA), labeled for improvement of milk quality and approved for use in organic production by the Ohio Ecological Food and Farm Association (Columbus). Phyto-Mast has some effectiveness in curing infections during the dry period when used as dry cow therapy (Mullen et al., 2014). Presence of the essential oil of Thymus vulgaris (thyme) in the formula may account for antibacterial action. Essential oil of thyme has strong antibacterial activity (Cowan, 1999; Kalemba and Kunicka, 2003) and contains a phenolic molecule called thymol that has strong activity against gram-negative bacteria (Helander et al., 1998) and common mastitis-causing pathogens (Ananda Baskaran et al., 2009). 
The study objective was to investigate antimicrobial activity of oils from each herbal component of PhytoMast in milk against common mastitis-causing pathogens cultured in vitro.

\section{Bacterial Cultures}

Single isolates of Staph. aureus, Staphylococcus chromogenes, and Streptococcus uberis were obtained from clinical mastitis cases on North Carolina dairy farms by the Milk Quality and Mastitis Laboratory at the College of Veterinary Medicine at North Carolina State University (Raleigh). Isolates were plated on Trypticase soy agar with $5 \%$ sheep blood (TSA; Becton, Dickinson and Co., Franklin Lakes, NJ). Purity of each culture was confirmed by Gram stain, morphology on mannitol salt agar (Staph. aureus and Staph. chromogenes), and morphology on blood agar (Strep. uberis). Bacteria were grown on TSA plates for $18 \mathrm{~h}$ in preparation for testing, and then kept refrigerated for the duration of the experiment. For each replication of each treatment tested, 1 colony was removed from the refrigerated plate and placed into $3 \mathrm{~mL}$ of Mueller-Hinton broth. Bacteria were grown to the midpoint of the $\log$ phase $[6 \mathrm{~h}$ for Staph. aureus and Staph. chromogenes (Fujikawa and Morozumi, 2006), and $3 \mathrm{~h}$ for Strep. uberis (Almeida and Oliver, 1993)] before beginning the experiment.

\section{Herbal Oils}

Canola oil extractions of 4 different herbs and essential oil of thyme were obtained from Herbal Vitality Inc. (Sedona, AZ). The 4 herbs included Angelica dahurica, Angelica sinensis, Gaultheria procumbens (wintergreen), and Glycyrrhiza uralensis (Chinese licorice). Plant oils were kept refrigerated in brown glass bottles to prevent light degradation or volatilization of the oils.

\section{Experimental Design}

Herbal oils were tested at concentrations of $0.5,1$, 2 , and $4 \%$ ( $\mathrm{vol} / \mathrm{vol}$ ). Those concentrations would theoretically be achievable in the pre-dry-off udder quarter, provided that milk production was approximately 2.45 $\mathrm{kg} /$ quarter per day ( $5.4 \mathrm{lb} /$ quarter per day). Because of the known antibacterial activity of thyme essential oil, it was tested by itself at concentrations of 1,2 , and $3 \%$ (vol/vol). The other 4 herbal oils were tested alone and in 15 combinations at each test concentration $(0.5$, 1,2 , and $4 \%$ ), for a total of 60 combinations. Combination treatments were prepared by mixing equal (vol/ vol) amounts of each of the oils to a total volume of 5 $\mathrm{mL}$ in a $10-\mathrm{mL}$ vial: 6 mixes of 2 oils each at $2.5 \mathrm{~mL}$, 4 mixes of 3 oils each at $1.67 \mathrm{~mL}$, and 1 mix of 4 oils each at $1.25 \mathrm{~mL}$. Vials containing oil preparations were kept sealed and refrigerated when not in use. All oilcontaining vials were vortexed for $15 \mathrm{~s}$ before beginning each trial.

Several controls were included in every testing of each treatment. Milk was cultured alone as a negative control to ensure that pasteurization was successful. An antibiotic control included milk + bacteria + penicillinstreptomycin at 1 and $5 \%$ concentrations, using the same antibiotic control as in a dry cow study (Mullen et al., 2014). The positive control was milk + bacteria, to document growth of bacteria in the milk. PhytoMast was also tested at 1, 2, 3, and $4 \%$ concentrations. Canola oil was tested at 1 and $70 \%$ concentrations to determine if it had an antibacterial effect without the herbal extract. For each bacterial species, 3 replicates of every treatment were tested at every concentration and control. Replicates were randomized by date, bacterium, and treatment to minimize experimental bias.

\section{Antibacterial Activity Testing}

Herbal oils were tested using a modified protocol for broth dilution testing (CLSI, 2008). Whole UHT pasteurized and homogenized organic milk was purchased from a grocery store and used instead of Mueller-Hinton broth as the growth medium. Vials were prepared for testing each control and treatment by first adding a calculated volume of milk, and then adding the volume of treatment solution to reach the percentage by volume $(0.5,1,2$, or $4 \%)$ tested. Following addition of treatments to milk, vials were vortexed for $90 \mathrm{~s}$. Ten microliters of the inoculated Mueller-Hinton broth was added, and then the test vials were vortexed for another $15 \mathrm{~s}$ and placed in an incubator at $37^{\circ} \mathrm{C}$ for $24 \mathrm{~h}$. Test vials contained a total of $1 \mathrm{~mL}$ of liquid.

Following incubation, vials were vortexed for $15 \mathrm{~s}$. Serial dilution was used to determine bacterial counts, using a $0.1-\mathrm{mL}$ aliquot from the vortexed vial and sterile $0.85 \%$ saline solution to create eight 10-fold dilutions. Dilutions were plated on eighths of a TSA plate and incubated for $24 \mathrm{~h}$ at $37^{\circ} \mathrm{C}$. Colony-forming units of all dilutions were recorded. Colony counts from the lowest readable dilution were used in the analysis (Miles and Misra, 1938).

\section{Analyses}

Results are reported as growth of bacteria in the treatment sample relative to the growth of the milk + bacteria control, as a percentage of the growth of the control. Treatments were considered successful at reducing bacterial growth if all 3 replications resulted in reduction of bacterial growth compared with the 
control. The ability of each treatment to completely eliminate bacterial growth was assessed using PROC MIXED in SAS (version 9.2; SAS Institute Inc., Cary, NC). The model was $Y=\mathbf{X} \boldsymbol{\beta}+\varepsilon$, where $Y$ represents the number of colony-forming units present after treatment, averaged across all 3 replications; $\boldsymbol{\beta}$ is a vector of fixed effects, including treatment and concentration with known design matrix $\mathbf{X}$; and $\varepsilon$ is the error term. In other words, the average number of colony-forming units present in the sample following treatment was modeled using treatment and concentration as explanatory variables. Each treatment was evaluated to determine if the mean percentages of bacterial growth for each treatment were significantly different from 0 . If this test did not yield a significant $P$-value $(P<0.05)$, the treatment was considered to have the ability to completely eliminate bacterial growth.

\section{Control Observations}

Both 1 and 5\% concentrations of penicillin-streptomycin were bactericidal for all replications of the 3 bacteria tested (Table 1). Every test run of milk alone also resulted in no bacterial growth for all replications of all bacteria. The positive control, milk + bacteria, had bacterial growth for all replications of all bacteria. All replications with canola oil at both 1 and $70 \%$ had no effect on bacterial growth.

\section{Efficacy Against Staphylococcus aureus}

Numbers of colony-forming units per milliliter present in the milk + bacteria controls for Staph. aureus were $8 \times 10^{8}$ for replication $1,2 \times 10^{8}$ for replication 2 , and $4.7 \times 10^{8}$ for replication 3 . Thyme oil killed all bacteria present at concentrations of 2 and $3 \%$ and was the only herbal treatment with the ability to completely eliminate bacterial growth (Table 1). No other oils or oil combinations consistently reduced bacterial growth
(Table 2), and variation in results for all concentrations were similar to those presented in Table 2 .

\section{Efficacy Against Staphylococcus chromogenes}

Numbers of colony-forming units present in the milk + bacteria controls for Staph. chromogenes were $1.1 \times$ $10^{8}$ for replication $1,1.5 \times 10^{8}$ for replication 2 , and $1.3 \times 10^{8}$ for replication 3 . Thyme oil at 2 and $3 \%$ was bactericidal, preventing Staph. chromogenes from multiplying and killing all bacteria that were inoculated into the thyme-containing vials. Thyme oil was the only herbal treatment with the ability to completely eliminate growth of Staph. chromogenes (Table 1). All herbal treatments reduced bacterial growth of Staph. chromogenes as compared with the control, but not significantly so (Table 2).

\section{Efficacy Against Streptococcus uberis}

Numbers of colony-forming units present in the milk + bacteria controls for Strep. uberis were $4 \times 10^{8}$ for replication $1,4.7 \times 10^{8}$ for replication 2 , and $4 \times 10^{8}$ for replication 3 . Thyme oil at 2 and $3 \%$ was bactericidal versus Strep. uberis and the $1 \%$ concentration also reduced growth of Strep. uberis significantly (Table 1). Thyme oil was the only herbal treatment with the ability to completely eliminate growth of Strep. uberis.

Kalemba and Kunicka (2003) noted that herbal essential oils are promising alternatives to synthetic antibiotics because of availability, biodegradability, and probable low risk of side effects. The current study leads us to conclude that 4 of the plant-derived oils tested were not effective as antimicrobial agents for mastitis treatments, although they may have antiinflammatory or analgesic effects as documented in other species (Poppenga, 2002; Abe et al., 2003; Kai et al., 2003; Kang et al., 2008; Genovese et al., 2009). Only thyme oil had antibacterial activity against all patho-

Table 1. Plant-derived oils and antibiotics and their effect on growth of mastitis-causing organisms in milk in vitro

\begin{tabular}{|c|c|c|c|c|c|}
\hline \multirow[b]{2}{*}{ Mastitis-causing organism } & \multirow[b]{2}{*}{ Treatment } & \multicolumn{4}{|c|}{$\begin{array}{l}\text { Growth of bacteria relative to control at various } \\
\text { concentrations (vol/vol) of treatment }{ }^{1}(\%)\end{array}$} \\
\hline & & $5 \%$ & $3 \%$ & $2 \%$ & $1 \%$ \\
\hline Staphylococcus chromogenes & $\begin{array}{l}\text { Thymus vulgaris } \\
\text { Penicillin-streptomycin }\end{array}$ & $0 \pm 0$ & $0 \pm 0$ & $0 \pm 0$ & $\begin{aligned} 35 & \pm 15 \\
0 & \pm 0\end{aligned}$ \\
\hline
\end{tabular}

${ }^{1}$ Growth of bacteria are presented as growth relative to the milk + bacteria control, averaged over 3 replications and presented as mean \pm SE. For example, at $1 \%$ concentration, Thymus vulgaris had $137 \%$ of the bacterial growth of the control, whereas no growth was observed at 2 and $3 \%$ concentrations of Thymus vulgaris essential oil.

${ }^{2}$ Thymus vulgaris $=$ essential oil of thyme. 
Table 2. Plant-derived oils and combinations of oils and their effect on growth of mastitis-causing organisms in milk in vitro

\begin{tabular}{|c|c|c|c|}
\hline \multirow[b]{2}{*}{ Treatment $^{1}$} & \multicolumn{3}{|c|}{$\begin{array}{l}\text { Growth of bacteria relative to control at } 4 \% \\
\text { concentration (vol/vol) of treatment }{ }^{1}(\%)\end{array}$} \\
\hline & $\begin{array}{l}\text { Staphylococcus } \\
\text { aureus }\end{array}$ & $\begin{array}{l}\text { Staphylococcus } \\
\text { chromogenes }\end{array}$ & $\begin{array}{l}\text { Streptococcus } \\
\text { uberis }\end{array}$ \\
\hline Angelica dahurica & $88 \pm 27$ & $52 \pm 31$ & $102 \pm 31$ \\
\hline Angelica sinensis & $139 \pm 34$ & $42 \pm 24$ & $143 \pm 52$ \\
\hline Gaultheria procumbens & $108 \pm 32$ & $65 \pm 43$ & $159 \pm 58$ \\
\hline Glycyrrhiza uralensis & $52 \pm 31$ & $51 \pm 25$ & $138 \pm 67$ \\
\hline A. dahurica, A. sinensis & $108 \pm 47$ & $42 \pm 24$ & $138 \pm 49$ \\
\hline A. dahurica, Ga. procumbens & $218 \pm 86$ & $45 \pm 18$ & $119 \pm 55$ \\
\hline A. dahurica, Gl. uralensis & $130 \pm 65$ & $43 \pm 16$ & $139 \pm 36$ \\
\hline A. sinensis, Ga. procumbens & $160 \pm 70$ & $47 \pm 21$ & $104 \pm 46$ \\
\hline A. sinensis, Gl. uralensis & $149 \pm 76$ & $53 \pm 31$ & $139 \pm 36$ \\
\hline Ga.procumbens, Gl. uralensis & $157 \pm 61$ & $34 \pm 13$ & $114 \pm 38$ \\
\hline A. dahurica, A. sinensis, Ga. procumbens & $136 \pm 50$ & $50 \pm 25$ & $125 \pm 42$ \\
\hline A. dahurica, A. sinensis, Gl. uralensis & $85 \pm 22$ & $47 \pm 16$ & $154 \pm 29$ \\
\hline A. dahurica, Ga. procumbens, Gl. uralensis & $113 \pm 44$ & $55 \pm 38$ & $115 \pm 44$ \\
\hline A. sinensis, Ga. procumbens, Gl. uralensis & $77 \pm 16$ & $59 \pm 31$ & $147 \pm 69$ \\
\hline A. dahurica, A. sinensis, Ga. procumbens, Gl. uralensis & $131 \pm 13$ & $37 \pm 7$ & $133 \pm 63$ \\
\hline Phyto-Mast $^{3}$ & $237 \pm 107$ & $47 \pm 16$ & $114 \pm 58$ \\
\hline
\end{tabular}

${ }^{1}$ Growth of bacteria are presented as growth relative to the milk + bacteria control, averaged over 3 replications and presented as mean \pm standard error. Treatments were also tested at 2,1 , and $0.5 \%$ concentration (vol/vol) and had large standard errors similar to those values reported here.

${ }^{2}$ Gaultheria procumbens $=$ wintergreen; Glycyrrhiza uralensis $=$ Chinese licorice.

${ }^{3}$ Phyto-Mast (Bovinity Health LLC, Narvon, PA) contains all of the listed plant oils and thyme essential oil (Thymus vulgaris) and is an intramammary herbal preparation used for improving milk quality.

gens tested, and was consistently effective at concentrations of $2 \%$ or greater.

The broth dilution method is often used to assess antibacterial efficacy of different essential oils (Hood et al., 2003) but milk was used instead of broth in the current experiment to simulate the environment of the udder. Lipids found in whole milk may have hydrophobic properties that could bind or decrease the antimicrobial properties of essential oils against mastitis-causing pathogens (Burt, 2004). This potential association between herbal oils and milk fat, as well as other lipophilic molecules in milk, is why whole milk was chosen as the in vitro model for evaluating antibacterial activity in the current study.

The testing method used resulted in large variations in bacterial growth within replications of the experiment and across the concentration levels. Although only the results at the $4 \%$ concentration of all plant oils were reported, the variation and inconsistency in results was also seen at the other tested concentrations. Replications were conducted on different days and a new carton of whole milk was used for each replication, both of which could have added variability to the experiment. The milk production level at dry-off that was assumed in this study is low $(9.8 \mathrm{~kg} / \mathrm{d}$, or $21.6 \mathrm{lb} / \mathrm{d})$ for conventional herds, but cows are often at or below such milk yields at dry-off in organic herds (K. A. E.
Mullen, personal observation). Cows with higher milk production would likely need higher doses to achieve desired concentrations in milk.

The proprietary composition of Phyto-Mast was not available to us for this research, and concentrations of ingredients tested may not be representative of the full formula of Phyto-Mast. Since the current study was completed, the formula of Phyto-Mast was altered to include more thyme essential oil (H. Karreman, Bovinity Health LLC, Narvon, PA; personal communication). Neither Phyto-Mast nor plant essential oils have been approved by the US Food and Drug Administration for intramammary use in cattle.

Essential oil of thyme at 2 and $3 \%$ had consistent antibacterial activity against the 3 mastitis-causing pathogens tested (Staph. aureus, Staph. chromogenes, and Strep. uberis), whereas none of the other oils or combinations of oils tested in this experiment showed evidence of antibacterial activity. Further investigations of in vivo effects of thyme oil alone or in various preparations on mastitic organisms would be of interest.

\section{ACKNOWLEDGMENTS}

This project was funded in part by a USDA Southern Region Sustainable Agriculture Research and Education Grant (Athens, GA). 


\section{REFERENCES}

Abe, M., F. Akbar, A. Hasebe, N. Horiike, and M. Onji. 2003. Glycyrrhizin enhances interleukin-10 production by liver dendritic cells in mice with hepatitis. J. Gastroenterol. 38:962-967.

Almeida, R. A., and S. P. Oliver. 1993. Growth curve, capsule expression and characterization of the capsular material of selected strains of Streptococcus uberis. Zentralbl. Veterinärmed. B 40:697-706.

Ananda Baskaran, S., G. W. Kazmer, L. Hinckley, S. M. Andrew, and K. Venkitanarayanan. 2009. Antibacterial effect of plant-derived antimicrobials on major mastitis pathogens in vitro. J. Dairy Sci. 92:1423-1429.

Burt, S. 2004. Essential oils: Their antibacterial properties and potential applications in foods-A review. Int. J. Food Microbiol. 94:223-253.

CLSI (Clinical and Laboratory Standards Institute). 2008. Performance standards for antimicrobial disk and dilution susceptibility tests for bacteria isolated from animals; approved standardThird Edition. Volume 28. Document M31-A3. CLSI, Wayne, PA.

Cowan, M. M. 1999. Plant products as antimicrobial agents. Clin. Microbiol. Rev. 12:564-582.

Electronic Code of Federal Regulations. 2013. Title 7: Agriculture Part 205-National Organic Program. Accessed May 4, 2013. http:// www.ecfr.gov/cgi-bin/text-idx?c $=$ ecfr\&SID $=$ f942f8fe8cf4407c29e5 0053befcc89a\&tpl=/ecfrbrowse/Title07/7cfr205_main_02.tpl.

Fujikawa, H., and S. Morozumi. 2006. Modeling Staphylococcus aureus growth and enterotoxin production in milk. Food Microbiol. 23:260-267.

Genovese, T., M. Menegazzi, E. Mazzon, C. Crisafulli, R. Di Paola, M. Dal Bosco, Z. Zou, H. Suzuki, and S. Cuzzocrea. 2009. Glycyrrhizin reduces secondary inflammatory process after spinal cord compression injury in mice. Shock 31:367-375.

Helander, I. M., H.-L. Alakomi, K. Latva-Kala, T. Mattila-Sandholm, I. Pol, E. J. Smid, L. G. M. Gorris, and A. von Wright. 1998 Characterization of the action of selected essential oil components on gram-negative bacteria. J. Agric. Food Chem. 46:3590-3595.

Hood, J. R., J. M. Wilkinson, and H. M. Cavanaugh. 2003. Evaluation of common antibacterial screening methods utilized in essential oil research. J. Essent. Oil Res. 15:428-433.
Kai, K., K. Komine, K. Asai, T. Kuroishi, Y. Komine, T. Kozutsumi, M. Itagaki, M. Ohta, Y. Endo, and K. Kumagai. 2003. Anti-inflammatory effects of intramammary infusions of glycyrrhizin in lactating cows with mastitis caused by coagulase-negative staphylococci. Am. J. Vet. Res. 64:1213-1220.

Kalemba, D., and A. Kunicka. 2003. Antibacterial and antifungal properties of essential oils. Curr. Med. Chem. 10:813-829.

Kang, O.-H., H.-S. Chae, Y.-C. Oh, J.-G. Choi, Y.-S. Lee, H.-J. Jang, J.-H. Kim, Y. C. Kim, D. H. Sohn, H. Park, and D.-Y. Kwon. 2008. Anti-nociceptive and anti-inflammatory effects of Angelicae dahuricae radix through inhibition of the expression of inducible nitric oxide synthase and NO production. Am. J. Chin. Med. 36:913-928.

Karreman, H. J. 2007. Treating Dairy Cows Naturally: Thoughts \& Strategies. Acres USA, Austin, TX.

Miles, A. A., and S. S. Misra. 1938. The estimation of the bactericidal power of blood. J. Hyg. (Lond.) 38:732-749

Mullen, K. A. E., L. G. Sparks, R. L. Lyman, S. P. Washburn, and K. L. Anderson. 2013. Comparisons of milk quality on North Carolina organic and conventional dairies. J. Dairy Sci. 96:6753-6762.

Mullen, K. A. E., S. P. Washburn, and K. L. Anderson. 2014. Effect of two herbal intramammary products on milk quality and quantity compared with conventional and no dry cow therapy. J. Dairy Sci. 97:3509-3522.

Organic Trade Association. 2011. U. S. organic industry overview. Accessed Sep. 1, 2013. http://www.ota.com/pics/documents/2011 OrganicIndustrySurvey.pdf.

Pol, M., and P. L. Ruegg. 2007a. Relationship between antimicrobial drug usage and antimicrobial susceptibility of gram-positive mastitis pathogens. J. Dairy Sci. 90:262-273.

Pol, M., and P. L. Ruegg. 2007b. Treatment practices and quantification of antimicrobial drug usage in conventional and organic dairy farms in Wisconsin. J. Dairy Sci. 90:249-261.

Poppenga, R. H. 2002. Herbal medicine: Potential for intoxication and interactions with conventional drugs. Clin. Tech. Small Anim. Pract. 17:6-18.

Ruegg, P. L. 2009. Management of mastitis on organic and conventional dairy farms. J. Anim. Sci. 87:43-55. 